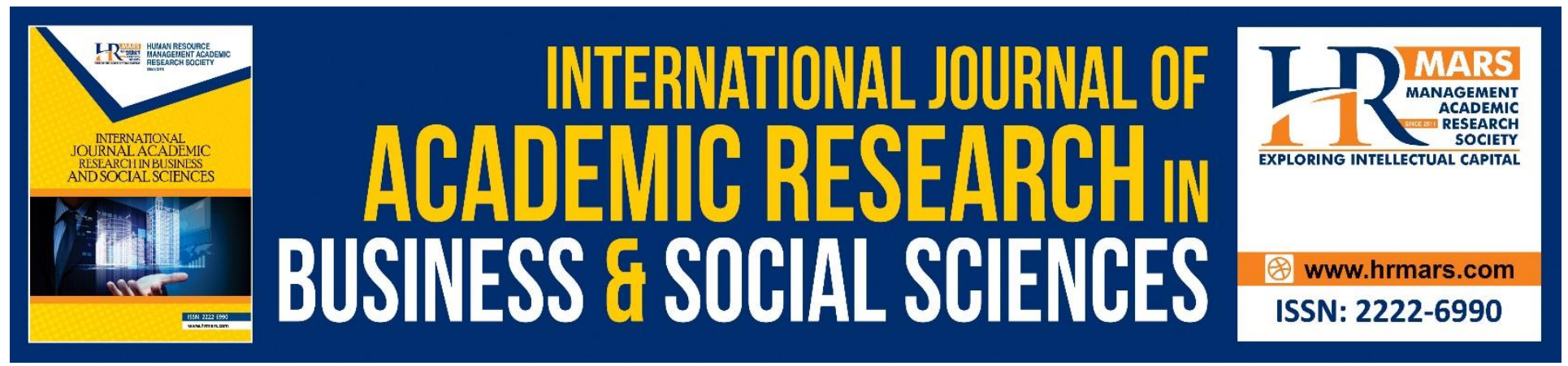

\title{
Development of ChemDataLog Module and Determination of Its Content Validity and Reliability
}

\author{
Punia Turiman, Kamisah Osman and Tengku Siti Meriam Tengku Wook
}

To Link this Article: http://dx.doi.org/10.6007/IJARBSS/v8-i12/5437

DOI: $10.6007 /$ IJARBSS/v8-i12/5437

Received: 24 Nov 2018, Revised: 22 Dec 2018, Accepted: 29 Dec 2018

Published Online: 07 Jan 2019

In-Text Citation: (Turiman, Osman, \& Wook, 2018)

To Cite this Article: Turiman, P., Osman, K., \& Wook, T. S. M. T. (2018). Development of ChemDataLog Module and Determination of Its Content Validity and Reliability. International Journal of Academic Research in Business and Social Sciences, 8(12), 2265-2277.

Copyright: (C) 2018 The Author(s)

Published by Human Resource Management Academic Research Society (www.hrmars.com)

This article is published under the Creative Commons Attribution (CC BY 4.0) license. Anyone may reproduce, distribute, translate and create derivative works of this article (for both commercial and non-commercial purposes), subject to full attribution to the original publication and authors. The full terms of this license may be seen

at: $\underline{\text { http://creativecommons.org/licences/by/4.0/legalcode }}$

Vol. 8, No. 12, 2018, Pg. 2265 - 2277

http://hrmars.com/index.php/pages/detail/IJARBSS

JOURNAL HOMEPAGE

Full Terms \& Conditions of access and use can be found at http://hrmars.com/index.php/pages/detail/publication-ethics 


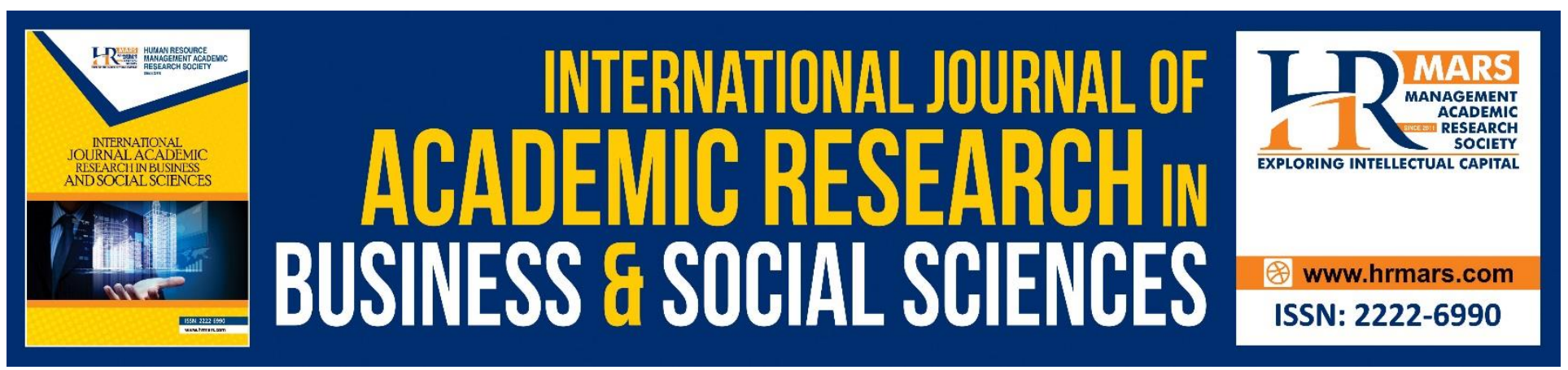

\title{
Development of ChemDataLog Module and Determination of Its Content Validity and Reliability
}

\author{
Punia Turiman, Kamisah Osman and Tengku Siti Meriam Tengku \\ Wook \\ Universiti Kebangsaan Malaysia, Malaysia
}

\begin{abstract}
ChemDataLog Module is developed to elevate chemistry achievement among preparatory course science students. ASSURE learning model was chosen for the researchers to design chemistry practical that aided by Microcomputer Based Laboratory (MBL). 5E Model of Inquiry Based Learning (IBL) was the learning strategy applied in using the module during chemistry practical class. A need assessment has been conducted among 170 Year Two students and seven Chemistry teachers of that preparatory course. Findings from the need assessment revealed that Organic Chemistry, Chemical Bonding, and Acid and Base were amongst three most difficult chemistry topics to learn perceived by the students. Meanwhile Organic Chemistry, Acid and Base, and Chemical Bonding were amongst three most difficult topics from teachers' perspectives. Besides, Electrochemistry, Acid and Base, and Thermochemistry were amongst three suitable topics to incorporate MBL from teachers' opinions. Therefore, Acid and Base, and Thermochemistry topics were selected for this module. This module comprised of six practical units. The content of this module was validated by six chemistry experts while the appropriateness of the language used was validated by two language experts. Feedbacks from the experts showed that they have a high agreement on the module's content validity. Meanwhile, the reliability of the module was determined from the questionnaires given to 64 students who used the module. Findings demonstrated that ChemDataLog Module has a high module reliability. This module is ready to be used as a learning instruction in elevating chemistry achievement among preparatory course science students.

Keywords: Module, Chemistry, 5e Model, Microcomputer Based Laboratory (MBL), Content Validity, Module Reliability
\end{abstract}

\section{Introduction}

Chemistry preparatory courses are needed for students to further their studies to advanced chemistry courses such as analytical chemistry and forensic chemistry or STEM (Science, Technology, Engineering, Mathematics) related courses such as engineering, medicine and healthcare in tertiary education. Chemistry is a field in science that studies macroscopic and microscopic matter, 
INTERNATIONAL JOURNAL OF ACADEMIC RESEARCH IN BUSINESS AND SOCIAL SCIENCES

Vol. 8, No. 12, Dec, 2018, E-ISSN: 2222-6990 @ 2018 HRMARS

interaction between matter and their products' uses (Gilbert \& Treagust, 2009). However, preparatory course students at college found that it is a difficult and challenging subject to understand (Laundonia \& Eilks, 2018; Sachel et al., 2014; Xu, Villafane \& Lewis, 2013). This is due to the nature of Chemistry that involves a lot of abstract concepts which hardly seen or understood. Besides, students must be able to comprehend the chemical reaction with macroscopic, microscopic and symbolic representation (Johnstone, 2006). Among the topics that are reported difficult for chemistry college students are organic chemistry (Kan, Cha \& Chia, 2015; O'Dwyer \& Child, 2017), electrochemistry (Rollnick \& Mavhunga, 2014), and acid and base (Cetin-Dindara \& Gebanb, 2016; Demircioglu, Ayas \& Demircioglu, 2005). Despite of its importance as required subject to further to tertiary education, students struggle in studying and securing good grades in Chemistry.

Chemistry educators consistently carry out research to provide instruction materials and innovative pedagogies to overcome students' difficulties in learning chemistry. Teaching of practical work in a physical lab is still seen as a significant part of effective pedagogy in science subjects including chemistry (Chairam, Ubon \& Coll, 2015). This allows students to develop a deep and longterm understanding of students' concepts which is the aim of chemistry teaching and learning. A foundation for teaching chemistry practical should be designed based on how students learn chemistry practices and methods involving macroscopic observable phenomena (Adlim et al., 2014). Then only these observable phenomena serve as a link for understanding more abstract representation which are microscopic and symbolic (Jansoon, Coll \& Samsook, 2009). Furthermore, a minimum standard required for a part of chemistry teaching should include inquiry-based laboratory in providing a fundamental for abstract concepts and to increase students' disposition toward Chemistry (National Research Council, 2012). With the aid of technology nowadays, the teaching of practical work can be enhanced with the incorporation of digital technologies such as computer, iPad and Microcomputer Based Laboratory (MBL).

MBLs are electronic devices, usually based on a digital processor or a computer. These devices are small, portable, battery powered, and built-in internal memory for data storage, and sensors to read the external data (Kale, 2015). Some MBLs are stand-alone with sensors where the captured data is stored in their internal memory for later offline processing. They can capture and store the physical data for use at a later time. The data collected can be pressure. temperature, voltage, current, power, displacement, flow or any other physical, chemical, or electrical parameter (Ibrahim, 2010). In chemistry practical teaching, MBL can be used to measure concentration, enthalpy change, electrode potential, reaction rate and etc.

Students can experience a real experience in the process of scientific inquiry (Liu et al., 2017). The actual inquiry-based experiences with the use of MBL can promote students' conceptual understanding (Gunhaart \& Srisawasdi, 2012). This approach allows students to interact directly with physical phenomena or with data gathering real-time from the phenomena (Pyatt \& Sims, 2011) and hence further enhances effective scientific learning (Hofstein \& Lunetta, 2004). Due to that, MBL could be used as a cognitive tool to enhance the understanding of scientific concepts in science laboratories teaching. Therefore, this study focuses on the development of chemistry practical module, ChemDataLog Module that aided with MBL in elevating students' achievement. 
INTERNATIONAL JOURNAL OF ACADEMIC RESEARCH IN BUSINESS AND SOCIAL SCIENCES

Vol. 8, No. 12, Dec, 2018, E-ISSN: $2222-6990$ @ 2018 HRMARS

\section{The underlying theory of ChemDataLog Module development}

The development of ChemDataLog Module is based on two learning theories: Social Constructivism Theory and Cognitive Load Theory.

\section{Social Constructivism Theory}

Social Constructivism Theory was the contribution of Lev Vygotsky, a Russian developmental psychologist. In this theory, Vygotsky believed that children learn from their social and cultural interaction (Vygotsky, 1978). These interactions are meant by children are not only interacting with their peers but also with people who are more knowledgeable than them or other word described as a more knowledgeable other (MKO). Vygotsky also generated the idea of a zone of proximal development (ZPD). ZPD is defined as the difference between what a learner could achieve on his own as compared to the help from a more knowledgeable other (MKO). MKO can be either children own peer or their teacher in a class setting. ZPD was more imperative when children learn new things as compared to what they have learned before.

In the context of this study, the students will carry out the experiments in a group. They will interact and collaborate with their peers in the group. Besides, the role of teacher as MKO will support the students to achieve the learning outcomes outlined in the module. The students would have better learning environment as they collaborate with their peers and have the support from the teacher. In addition, the use of MBL in the practical will allow students to interact with the technology that helps them in managing and processing their data real-time.

\section{Cognitive Load Theory}

Cognitive Load Theory is one of the most popular theories in instructional design field. This theory is much related to Cognitive Theory that discuss about schema formation in a learning process. It was based on the premise that instructional design should consider ways to minimize cognitive load to the learner (Sweller, 1999). This should be making sense as less cognitive load a learner shall carry, the easier the learning shall take place. Working memory or so-called short-term memory might have negative effect on learning (Sweller, 1994; Sweller \& Chandler, 1994; Yeung, 1999). Schema are believed to be formed in short-term memory and finally become automatized because of practice. Processing information in learning instructions may incur cognitive load and have an adverse effect on learning outcomes.

In the context of this study, the module is designed in such a way the students can easily follow the instruction in the module. Meanwhile, the incorporation of Microcomputer Based Laboratory $(\mathrm{MBL})$ in the practical work can facilitate students by simplifying procedures of data reading, data logging, data processing and displaying graph real-time. These can reduce students' time and they can focus more time to analyzing and explaining the experimental results. In addition, when the students interact directly with data gathering real-time, they can enhance their understanding of the chemistry concepts involved in the reaction. Therefore, MBL can reduce students' cognitive load and enhance effective chemistry learning. 
INTERNATIONAL JOURNAL OF ACADEMIC RESEARCH IN BUSINESS AND SOCIAL SCIENCES

Vol. 8, No. 12, Dec, 2018, E-ISSN: $2222-6990$ @ 2018 HRMARS

\section{Development of ChemDataLog Module}

The development of ChemDataLog Module is based on ASSURE instructional design model. ASSURE is the acronym for A - Analyze learner characteristics, S - State objectives, S - Select methods, media and materials, $U$ - Utilize technology, media and materials, R - Require learner participation, E Evaluate and revise (Smaldhino, Rusell, Heinich \& Molenda, 2006). Analyze learner characteristics means analyzing learners' characteristics to be aligned to the learning outcomes. Learners' characteristics will be analyzed into general characteristics, entry competencies and learning styles. State objectives means state the learning outcomes targeted to be achieved after completely use the learning instruction. The learning outcomes are taken from the syllabus of certain academic programme. Select methods, media and materials means selecting methods, media and materials that appropriate to learners' characteristics in order to achieve the learning outcomes. Utilize technology, media and materials means utilizing technology, media and materials to support the learning process. It is the role of the teacher to plan and execute so that the technology, media and materials are beneficial to students' learning. Require learner participation means the teacher keep the students to be active during the instruction. Evaluate and revise means the teacher evaluate the impact of the lesson on students' learning based on the learning outcomes. Besides students' achievement, teacher must also evaluate the entire instructional process and the effectiveness of using technology and media on the learning process (Smaldhino, Rusell, Heinich \& Molenda, 2006).

This ChemDataLog Module applies 5E Model for inquiry-based learning approach. 5E is referred to Engagement, Exploration, Explanation, Elaboration and Evaluation (Bybee et al., 2006). Unlike the theory that describes complex processes, models are used to simplify the process and make the process easier to understand. The $5 \mathrm{E}$ model is a popular version that underpins Constructivism Theory as students use prior knowledge to carry out the 5E Model activities (Demircioğlu, \& Çağatay 2014; Karsli \& Ayas, 2014). In addition, the 5E Model also incorporates mindbased, hands-on and science-based inquiries effectively (Liu, Andre \& Greenbowe, 2008). The 5E model is applied in these laboratories activities for students to directly engage, explore, explain, develop and evaluate their concepts in Chemistry.

Engagement refers to teacher engages students in a new concept using short activities or questions that promote curiosity and draw out prior knowledge in order to unveil students' knowledge. Exploration refers to students do not only conduct activities i.e. lab activities, group discussion, role playing but also explore questions and implement a preliminary investigation. Explanation refers to teacher has an opportunity to directly introduce a concept, process, skill so that students can imply their understanding of the concepts or tract their correct or incorrect understanding. Elaboration refers to students are immersed in their newly structured knowledge into a deeper and broader understanding in order to elaborate on their conceptual understanding and skills. Evaluation refers to students' comprehension and abilities are assessed and thereby the teacher is able to monitor students' progress in accomplishing the learning outcomes (Bybee et al., 2006).

A need assessment has been carried out among 170 Year Two students and eight Chemistry teachers of that preparatory course. Based on the findings, Organic Chemistry, Chemical Bonding, and Acid and Base were amongst three most difficult chemistry topics to learn from students' perspectives. Seven chemistry teachers were interviewed about three most difficult topics faced by 
students. Organic Chemistry, Acid and Base, and Chemical Bonding were amongst three most difficult topics from teachers' perspectives. Besides that, Electrochemistry, Acid and Base, and Thermochemistry were amongst three suitable topics to use MBL from teachers' opinions. As a result, Acid and Base, and Thermochemistry topics were selected for this module. This module consisted of six practical units. An example of a practical unit in the module is displayed in Table 1.

Table 1. An example of the practical unit in ChemDataLog Module

\begin{tabular}{|c|c|c|}
\hline \multicolumn{3}{|c|}{ Title of experiment: Acid and Base Titration Curve } \\
\hline Step & Activity & Instruction in the module \\
\hline Engagement (10 minutes) & $\begin{array}{l}\text { Teacher starts with a } \\
\text { short Kahoot game on } \\
\text { titration curve and } \\
\text { students participate in } \\
\text { the game. Teacher } \\
\text { connects the questions } \\
\text { in the game with the } \\
\text { experiment. } \\
\text { Then, teacher asks } \\
\text { students to carry out } \\
\text { the experiment in } \\
\text { groups. Each group } \\
\text { may consist of } 2-3 \\
\text { students. }\end{array}$ & $\begin{array}{l}\text { Link: } \\
\text { https://play.kahoot.it/\#/k/291c717b- } \\
\underline{\text { 74b0-4bcc-9d13-e7af8a79523a }}\end{array}$ \\
\hline Exploration (30 minutes) & $\begin{array}{l}\text { Students are asked to } \\
\text { carry out the } \\
\text { experiment using the } \\
\text { procedure given in the } \\
\text { module. }\end{array}$ & $\begin{array}{c}\text { The setup of titration experiment } \\
\text { with } \mathrm{MBL}\end{array}$ \\
\hline Explanation (30 minutes) & $\begin{array}{l}\text { Students are required } \\
\text { to present according to }\end{array}$ & Each group must do a presentation. \\
\hline
\end{tabular}




\begin{tabular}{|c|c|c|}
\hline & $\begin{array}{l}\text { the criteria given in } \\
\text { Data Analysis Section. } \\
\text { Each group will present } \\
\text { a titration curve from } \\
\text { the Logger Pro } \\
\text { Software for different } \\
\text { combination of acid } \\
\text { and base. Students are } \\
\text { needed to explain acid } \\
\text { base equation, salt } \\
\text { hydrolysis, equivalence } \\
\text { point and suitable } \\
\text { indicator for that } \\
\text { titration curve. }\end{array}$ & $\begin{array}{l}\text { Display titration curve from the } \\
\text { Logger Pro software for each } \\
\text { experiment. } \\
\text { The presentation must also include } \\
\text { the following points; } \\
\text { a) Type of acid and base used and its } \\
\text { initial pH value. } \\
\text { b) Acid base equation } \\
\text { c) Salt hydrolysis. } \\
\text { d) Equivalence point. } \\
\text { e) Suitable indicator. }\end{array}$ \\
\hline Elaboration (20 minutes) & $\begin{array}{l}\text { Students are asked to } \\
\text { answer the questions in } \\
\text { the exercise given in } \\
\text { the module. }\end{array}$ & $\begin{array}{l}\text { Answer the question. } \\
\text { Sketch the graph that would be } \\
\text { obtained for the titration of } 25.0 \mathrm{~cm}^{3} \\
\text { of } 0.100 \text { moldm}^{3} \text { propanoic acid with } \\
0.100 \text { moldm}^{-3} \text { potassium hydroxide } \\
\text { using bromophenol blue as an } \\
\text { indicator. Given pH range of } \\
\text { bromophenol blue is } 3.0-4.6 \text {. Is } \\
\text { bromophenol blue the suitable } \\
\text { indicator for this titration? } \\
\text { pH } \\
14 \\
12 \\
10 \\
8 \\
6 \\
4 \\
2\end{array}$ \\
\hline
\end{tabular}


INTERNATIONAL JOURNAL OF ACADEMIC RESEARCH IN BUSINESS AND SOCIAL SCIENCES

Vol. 8, No. 12, Dec, 2018, E-ISSN: 2222-6990 @ 2018 HRMARS

\begin{tabular}{|l|l|}
\hline Evaluation (10 minutes) & $\begin{array}{l}\text { Students are asked to } \\
\text { summarize the } \\
\text { differences among } \\
\text { titration curves due to } \\
\text { different combination } \\
\text { of acids and bases. } \\
\text { Teacher evaluates on } \\
\text { students' } \\
\text { understanding of acid } \\
\text { base titration curves. } \\
\text { Teacher concludes and } \\
\text { ends the lesson. }\end{array} \mid$ \\
\hline
\end{tabular}

\section{Results and Discussion}

ChemDataLog Module's content validity

The content of ChemDataLog Module was validated by six chemistry experts form local universities and colleges. All of them were qualified and well experienced in chemistry education. A Likert 5-point scale ranged from 1 to 5 (1- strongly disagree, 2-disagree, 3-less agree, 4-agree, 5-strongly agree) was employed for the experts to validate the content of the module. Findings revealed that the experts have given a high agreement on the content of the module. Some of the items and their means from the experts' validation are shown in Table 2.

Table 2. Chemistry experts' validation mean for the module content

\begin{tabular}{|l|l|c|}
\hline Item & Statement & Mean \\
\hline 1. & The content of this module is suitable for the targeted population. & 4.83 \\
\hline 2. & $\begin{array}{l}\text { The content of this module is suitable to be used by preparatory } \\
\text { course students. }\end{array}$ & 4.83 \\
\hline 3. & $\begin{array}{l}\text { The content of this module is aligned with the syllabus of } \\
\text { Chemistry preparatory course. }\end{array}$ & 4.67 \\
\hline 4. & $\begin{array}{l}\text { The content of this module is arranged from easy to difficult. } \\
\text { the time table. }\end{array}$ & 4.17 \\
\hline 5. & $\begin{array}{l}\text { The experiments prepared in this module can be conducted in the } \\
\text { allocated time. }\end{array}$ & 4.33 \\
\hline 6. & $\begin{array}{l}\text { Each sub-unit in this module can be carried out in the allocated } \\
\text { time. }\end{array}$ & 4.17 \\
\hline 8. & $\begin{array}{l}\text { This module provides a good explanation on the concept learned } \\
\text { by the students. }\end{array}$ & 4.17 \\
\hline 9. & $\begin{array}{l}\text { The exercise prepared in this module can enhance students' } \\
\text { understanding of chemistry concepts. }\end{array}$ & 4.33 \\
\hline 10. & $\begin{array}{l}\text { The content of this module can increase students' chemistry } \\
\text { performance. }\end{array}$ & 3.83 \\
\hline
\end{tabular}


INTERNATIONAL JOURNAL OF ACADEMIC RESEARCH IN BUSINESS AND SOCIAL SCIENCES Vol. 8, No. 12, Dec, 2018, E-ISSN: 2222-6990 @ 2018 HRMARS

\begin{tabular}{|l|l|c|}
\hline 11. & $\begin{array}{l}\text { The activities prepared in this module encourage students to } \\
\text { collaborate in a group. }\end{array}$ & 4.83 \\
\hline 12. & $\begin{array}{l}\text { The learning strategy used in this module is based on Social } \\
\text { Constructivism Theory. }\end{array}$ & 4.50 \\
\hline 13. & $\begin{array}{l}\text { The learning strategy used in this module is based on Cognitive } \\
\text { Load Theory. }\end{array}$ & 3.83 \\
\hline 14. & $\begin{array}{l}\text { The learning strategy used in this module is based on Inquiry Based } \\
\text { Learning (IBL) }\end{array}$ & 4.33 \\
\hline 15. & $\begin{array}{l}\text { The sub-unit activity in this module is arranged based on 5E Model } \\
\text { (Engage, Explore, Explain, Elaborate and Evaluate). }\end{array}$ & 4.33 \\
\hline & \multicolumn{2}{|r}{ Average of all means } \\
\hline
\end{tabular}

Based on Table 2, all items show means higher than 4.00 (mean=4.17 to 4.83) except for Item 10 and Item 13 that show means lower than 4.00 (mean=3.83). Item 1 shows the highest mean (mean=4.83) meanwhile Item 10 and Item 13 show the lowest mean (mean=3.83). However, average of all means shown is higher than 4.00 (mean=4.35). This implies that the chemistry experts have given a high agreement on the suitability of the module content.

Besides content validity, the appropriateness of language used in ChemDataLog Module was also validated by two language experts. They are experienced English teachers from a preparatory college. A rubric of yes or no choice was used for the experts to evaluate the language used in the module. Feedbacks from the experts demonstrated that the language used in the module was appropriate as shown in Table 3.

Table 3. Language experts' validation rubric for language used in the module

\begin{tabular}{|l|l|c|c|}
\hline Item & Statement & Expert 1 & Expert 2 \\
\hline 1. & Objectives of the module were clearly stated. & Yes & Yes \\
\hline 2. & Instruction in the module was clearly stated. & Yes & Yes \\
\hline 3. & Each sentence has a clear meaning. & Yes & Yes \\
\hline 4. & Language used in this module is easy to understand. & Yes & Yes \\
\hline 5. & Consistent terms are used throughout the module. & Yes & Yes \\
\hline 6. & Appropriate scientific terms used in this module. & Yes & Yes \\
\hline 7. & No typo errors in this module. & Yes & Yes \\
\hline 8. & Suitable font size used and easy to read. & Yes & Yes \\
\hline
\end{tabular}

It can be seen in Table 3 that both language experts have agreed on each item in the evaluation form. This indicates that they have a high agreement on the appropriateness of language used in the module.

ChemDataLog Module's reliability

The reliability of ChemDataLog Module was carried out using questionnaires. 64 students answered the questionnaires after they have completed using the module in the chemistry practical classes. The items were based on the practical unit. Cronbach Alpha was calculated from the students' 
INTERNATIONAL JOURNAL OF ACADEMIC RESEARCH IN BUSINESS AND SOCIAL SCIENCES

Vol. 8, No. 12, Dec, 2018, E-ISSN: 2222-6990 @ 2018 HRMARS

responses by using SPSS. The number of items and Cronbach Alpha of each practical are listed in Table 4.

Table 4. Cronbach Alpha for the module reliability

\begin{tabular}{|l|c|c|c|}
\hline Practical unit & N & No of item & Cronbach Alpha \\
\hline Practical_1 & 64 & 5 & 0.794 \\
\hline Practical_2 & 64 & 7 & 0.869 \\
\hline Practical_3 & 64 & 3 & 0.734 \\
\hline Practical_4 & 64 & 5 & 0.884 \\
\hline Practical_5 & 64 & 5 & 0.787 \\
\hline Practical_6 & 64 & 4 & 0.874 \\
\hline General on module & 64 & 7 & 0.919 \\
\hline Average of all Cronbach Alpha & 64 & 36 & 0.837 \\
\hline
\end{tabular}

Based on Table 4, the Cronbach Alpha of each practical is greater than 0.700 . The average of all Cronbach Alpha is 0.837 which is also greater than 0.700 . An instrument is highly reliable when the Cronbach Alpha is 0.70 and above (Fraenkel \& Wallen, 1996: Kerlinger, 1986). Therefore, this implies that ChemDataLog Module has a high module reliability.

\section{Conclusion}

Chemistry is a central subject for other STEM courses in tertiary eduacation yet students face difficulties in learning the subject. ChemDataLog Module is developed to enhance students' understanding through chemistry experiments. By using ASSURE learning model, this module is designed for the chemistry practicals aided with MBL. The activities in the practical units are arranged according to 5E Model that encourage science inquiry learning. The content of this module was validated by six chemistry experts and they have a high agreement on the content validity. The language experts also agreed with the appropriateness of language used in the module. The module reliabilty has been determined form the questionnaires given to students who used the module. Findings demonstrated that this ChemDataLog Module has a high module reliability. Thus, it can be concluded that this module is ready to be used as a learning instruction in elevating chemistry achievement among preparatory course students.

\section{Acknowledgement}

The authors would like to thank Chemistry teachers and students who have participated and given their full cooperation to this research.

\section{Corresponding Author}

Kamisah Osman, Faculty of Education, The National University of Malaysia, 43600 Bangi, Selangor, Malaysia. E-mail: kamisah@ukm.edu.my

\section{References}

Adlim, S., Soewarno, S., Ali, H., Ibrahim, A., Umar, H., \& Ismail, K. (2014). Assessing chemistry-learning competencies of students in isolated rural senior high schools by using the national examination: $A$ 
INTERNATIONAL JOURNAL OF ACADEMIC RESEARCH IN BUSINESS AND SOCIAL SCIENCES

Vol. 8, No. 12, Dec, 2018, E-ISSN: $2222-6990$ C 2018 HRMARS

case study of Simeulue Island, Indonesia. International Journal of Science and Mathematics Education, 12, 817-839.

Bybee, R. W., Taylor, J. A., Gardner, A., Van Scotter, P., Powell, J., Westbrook, A., \& Landes, N. (2006). The BSCS 5E instructional model: Origins and effectiveness. Colorado Springs, CO: Biological Sciences Curriculum Studies.

Chairam, S., Ubon, N.K. \& Coll, R.K. (2015). Exploring Secondary Students' Understanding of Chemical Kinetics through Inquiry-Based Learning Activities. Eurasia Journal of Mathematics, Science \& Technology Education, 11(5), 937-956.

Cetin-Dindra, A. \& Gebanb, O. (2016). Conceptual understanding of acids and bases concepts and motivation to learn chemistry. The Journal of Educational Research, 1-13.

Demircioglu, G., A. Ayas \& H. Demircioglu, 2005. Conceptual change achieved through a new teaching program on acids and bases. Chemistry Education Research and Practice, 6: 36-51.

Demircioglu, G. \& Cagatay, G. (2014). The effect of laboratory activities based on $5 \mathrm{E}$ model of constructivist approach on 9th grade students' understanding of solution chemistry, Procedia-Social and Behavioral Sciences, 116, $3120-3124$.

Gilbert, J. K.; Treagust, D. (2009). Multiple representations in chemical education: Dordrecht, The Netherlands: Springer.

Gunhaart, A., \& Srisawasdi, N. (2012). Effect of integrated computer-based laboratory environment on students' physics conceptual learning of sound wave properties. Procedia-Social and Behavioral Sciences, 46, 5750-5755.

Fraenkel, J.R. \& Wallen, N.E. (1996). How to Design and Evaluate Research in Education. $3^{\text {rd }}$ Edition. New York: Mc Graw Hill, Inc.

Hofstein, A., \& Lunetta, V. N. (2004). The laboratory in science education: Foundation for the 21st century. Science Education, 88, 28-54.

Ibrahim. D. (2010). A Data Logger for Teaching Data Capturing and Analysis to Engineering Students. Computer Application Engineering Education, 18, 397- 405.

Jansoon, N., Coll, R. K. \& Samsook, E. (2009). Understanding mental models of dilution in Thai students. International Journal of Environmental \& Science Education, 4, 147-168.

Johnstone, A. H. (2006). Chemical Education Research in Glasgow in perspective. Chemistry Education Research and Practice, 7(2), 49-63. 
INTERNATIONAL JOURNAL OF ACADEMIC RESEARCH IN BUSINESS AND SOCIAL SCIENCES

Vol. 8, No. 12, Dec, 2018, E-ISSN: $2222-6990$ C 2018 HRMARS

Kale, B. (2015). Smart phone based real time wireless data logger system. International Journal of Multidisciplinary Research and Development, 2(6), 258-261.

Kan, S-Y, Cha, J. \& Chia, P.W. (2015). A Case Study on Using Uncritical Inference Test to Promote Malaysian College Students' Deeper Thinking in Organic Chemistry. Journal of the Korean Chemical Society, 59(2), 1-8.

Karsli, F. \& Ayas, A. (2014). Developing a Laboratory Activity by Using 5E Learning Model on Student Learning of Factors Affecting the Reaction Rate and Improving Scientific Process Skills. Procedia Social and Behavioral Sciences, 143, $663-668$.

Kerlinger, E.N. (1986). Foundation of Behavioral Research. New York: Holt, Rinehart and Wiston.

Laudonia, I. \& Eilks, I., (2018). Reflections on a Three-Year-Long Teacher-Centered, Participatory Action Research Experience on Teaching Chemical Bonding in a Swiss Vocational School. Educ. Sci., 8, 141.

Liu, H., C., Andre, T. \& Greenbowe, T. (2008). The Impact of Learner's Prior Knowledge on Their Use of Chemistry Computer Simulations: A Case Study, Journal of Science Education and Technology, $17(5), 466-482$.

Liu, C.Y, Wu. C.J., Wong, W.K., Lien, Y.W., Chao, T.K. (2017). Scientific modelling with mobile devices in high school physics labs. Computers \& Education, 105, 44-56.

National Research Council (NRC). (2012). A framework for K-12 science education: Practices, crosscutting concepts, and core ideas. Washington, DC: National Academies Press.

O'Dwyer, A. \& Childs, P.E. (2017). Who says Organic Chemistry is Difficult? Exploring Perspectives and Perceptions. Eurasia Journal of Mathematics Science and Technology Education, 13(7), 3599-3620.

Pyatt, K., \& Sims, R. (2011). Virtual and physical experimentation in inquiry-based science labs: Attitudes, performances and access. Journal of Science Education and Technology, 21(1), 133-147.

Rollnick, M. \& Mavhunga. (2014). PCK of teaching electrochemistry in chemistry teachers: A case in Johannesburg, Gauteng Province, South Africa E. Educ. quím., 25(3), 354-362.

Sachel, M., Villafane, C., Garcia, A. \& Lewis, J.E. (2014). Exploring diverse students' trends in chemistry self-efficacy throughout a semester of college-level preparatory chemistry. Chemistry Education Research and Practice, 15, 114.

Smaldino, S.E., Rusell, J.D., Heinich, R. \& Molenda, M. (2006). Instructional Technology and Media for Learning. UK; Upper Saddle River. 
INTERNATIONAL JOURNAL OF ACADEMIC RESEARCH IN BUSINESS AND SOCIAL SCIENCES

Vol. 8, No. 12, Dec, 2018, E-ISSN: $2222-6990$ (C) 2018 HRMARS

Sweller, J. (1994). Cognitive load theory, learning difficulty and instructional design. Learning and Instruction, 4(4), 295-312.

Sweller, J. (1999). Instructional design in technical areas. Camberwell, Australia: ACER Press.

Sweller, J., \& Chandler, P. (1994). Why some material is difficult to learn. Cognition and Instruction, $12,185-233$.

Vygotsky, L. S. (1978). Mind in society: The development of higher psychological processes. Cambridge, MA: Harvard University Press.

Xu, X., Villafane, S.M. \& Lewis, J.E. (2013). College students' attitudes toward chemistry, conceptual knowledge and achievement: structural equation model analysis, Chemistry Education Research and Practice, 14, 188.

Yeung, A. S. (1999). Cognitive load and learner expertise: split attention and redundancy effects in reading comprehension tasks with vocabulary definitions. Journal of Experimental Education, 67(3), 197-221. 